\title{
疽
}

\section{溶接構造用鋼と窒化アルミニゥム $(\mathbf{1})^{*}$}

\section{長谷部茂雄**}

\section{Weldable Structural Steel and Aluminum Nitride(1)*}

By Shigeo Hasebe**

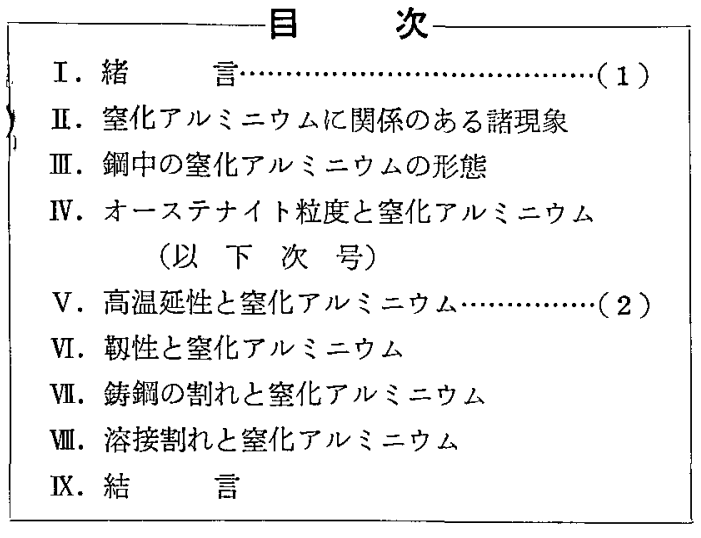

\section{I. 緒喜}

溶接構造用鋼にかぎらず， $\mathrm{Al}$ は溶鈯の脱酸を行なう ため，また，結晶粒度の調整のためなどに，さかんに使 用されている.

とくに溶接構造用の低炭索鋼および低合金鋼において は，結晶粒の微細化および歪時效脆化の防止による嚇性 の向上，さらに溶接熱影響部の硬化あるいは熱影㗽部の 組織の粗大化の防止などの目的で, $\mathrm{Al}$ が相当量添加さ れるのが普通である。

したがって，鋼の諸性質におよぼす Al の影響につい ては，てれまでにかなり多くの研究が行なわれてきてい る.

もっとも，鋼材の諸性質を改善するために，製鋼過程 において Al を添加するてとは, 今日ではまったく普通 のとととなっているが，Al がこのようにさかんに使用 されはじめたのは，比較的最近のことである.

Mc Quaid の結晶粒度の調整に関する研究1などによ り，A1 の影響がとくに注目されたのは1935年頃である が，1940年代に抬ける化学冶金学および化学分析技術の

* 原稿受付 昭和39年 6 月 29 日

**正員 住友金属工業中央技術研究所 Member, Central Research Laboratories, Sumitomo Metal Industries Ltd.
進歩ととむに，はじめて A1 の使用が一般化されるに至 ったあのと考えられる。

鋼の諸性質におよぼす $\mathrm{Al}$ の影響は，鋼中における $\mathrm{Al}$ の存在形態によって，原子状了ルミニウム，酸化了ルミ ニウム，窒化アルミニウム，さらに，硫化アルミニウム によるあのなどに分けて考えられる，すなわち，固溶元 菜としての影響と，てれらの各種のアルミニウム化合物 の影響とが考えられる．しかし，鋼中におけるてのよう な $\mathrm{Al}$ の存在形態のそれぞれの影響が，個別にわかって いるわけではない。

Al の添加の影響に関する初期の研究では, 各アルミ 二ウム化合物の分離定量ができないために，たとえば $\mathrm{lb} / \mathrm{ton}$ で表わされるような Al の添加量の多少によっ て，鋼がうける影響が調査されていたにすぎない，その のち, 酸可溶の $\mathrm{Al}$ の量との関連に扔いて調查が行なわ れてきた。

1949年に, Beeghly2) のエステル・ハロゲンによる窒 化アルミニウムの分離定量の成功によって，䤱中の窒化 アルミニウムの化学分析が可能になってからは，鋼中の A1 に関する研究にはいちじるしい進歩がみられた。.才 ーステナイト粒の微細化および粗粒化阻止のために添加 される Al の効果についての研究は，そのよい例であ る. この上うにして, 窒化アルミニゥムの形で存在する 鋼中の $\mathrm{Al}$ が, 多くの鋼化重要な影響をおよぼすととが 明らかになってきた。

ついで，筆者は1960年頃から，戦後急速に発達した電 子顕微鏡を使用して窒化アルミニウムの直接観察を行な い，鋼中の窒化アルミニウムの挙動を明かにするととが できた．その結果，窒化アルミニウムが関係している諸 現象の機構も明らかにするととができ，さらに新しい 二,三の現象む知るととができた。

以下，溶接構造用鋼の諸性質におよぼす窒化了ルミニ ウムの影響について，交献にみられるところを整理し て，その概要を紹介し，また，筆者の研究を中心に，鋼 
中の窒化アルミニウムがその諸性質におよぼす影響の機 構について説明しよう.

\section{II. 窒化アルミニウムに関係のある諸現象}

上にのべたように, Beeghly のエステル・八ロゲン

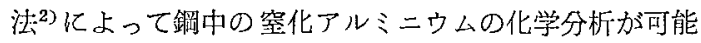
になってから，㧘化テルミニウムが多くの鋼の性質に重 要な影響をおよぼしているととが资第に明かになってき た。しかし，それはまだかなりばくぜんとした，定性的 なものであった。

なお，Beeghly 以前の鋼中の Al に関する文献につ いて，かなり古いものにさかのぼって調查しているうち に，窒化アルミニウムが関係していたのではないかと想 像される報告や，窒化アルミニウムの影響加現狆たも のに違いないものを，运って他の影響としてし志ったと 思われる報告が散見された。

\section{1）オーステナイト結晶粒度およひ粗粒化温度におよ ぼす影䉪}

よく知られているように，鋼のオーステナイト結晶粒 度の調整のためには，Al の添加が普通に行なわれてい Ђ.

A1 の添加がオーステナイト粒を微細にする効果のあ ることはすでに1935年の McQuaid の研究はよとによ り明らかにされていたが，Al がよ゙のような形でオース テナイト粒の微細化，あるいは粗粒化の阻止に影響をお よぼしてるかについては，此較的最近までいくつかの 仮説が論じられていたにすざない，すなわち，酸化アル ミニウムの微細な粒子によるとする説3,4)，オーステナ イトに固溶した原子状アルミニウムによるとする説(5), また，硫化アルミニウムの微細な粒子によるとする説 ${ }^{6}$ などであった。

Beeghly $^{2)}$ によって鋼中の窒化アルミニウムの化学分 析が行なわれるようになってからは，オーステナイト域 で析出する窒化アルミニウムの微細な粒子によるよする 説》がでて, 今日では，乙の穻化アルミニウム説がもっ とあ確かであろうと信じられている。

\section{2）焼入性および焼戻脆性におよぼす影響}

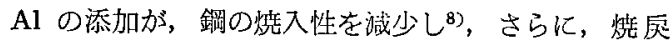
脆性を防止する効果”のあることも知られているが，乙 れらの現象は，鋼中の空化アルミニウムによる結晶粒徽 細化の間接的な影響によるものと考えられる.

\section{3）フェライト結晶粒の形状におよばす影輻}

鋼中の窒化アルミニウムがオーステナイト粒度に影響 をおよぼし，そのためにフェライト粒度に影㧛するとと
はいうまでもないが，てのほか，フェライト粒の形状に 屯影響することが知られている。

すなわち，窒化アルミニウムは低炭素アルミキルド鋼 の冷間王延後の再結昆組織に影響する ${ }^{10)}$. 冷間圧延後に 烍剑軟化処理が行なわれ，十分に再結昆が進んだのちに おいても，フェライト料は压延方向に引き伸ばされた，

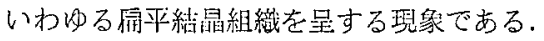

この現象について, Solter および Beattia ${ }^{11)}$ は, フ エライト中に析出する窒化アルミニウムが，再結晶粒の 成長を阻止する作用をおよばすためであるうとしてい る.また, Leslie, Rickett, Dotson および Walton ${ }^{12)}$ は，冷間圧延後に軟化処理を行なうときに，空化アルミ ニウムを固溶したフェライトが再結鼠温度に達するまえ に，窒化アルミニウムをその結晶䊀界に析出して，フェ ライトのその後の再結晶を阻害するためであるうと推察” している.

\section{4）鋳鋼の常温における衝椠值におよぼす影幚}

鋳鋜において，大型の公化アルミニウムの析出物が， 鋳鋼の常温におりる衝撃値を低下させることが知られて いる. Lorig 扰よび Elsea ${ }^{13)}$ によってはじめて研究さ れたもので，その破面の棁相から“rockcandy fracture” といわれているものである。

沖执よび小幡 ${ }^{14), 15)}$ によって屯，1次才ーステナイト粒 界の脆性として報告されているすのであるが，それによ る上，Al およざが $\mathrm{N}$ 比較的多星に存在する場合に，才 ーステナイトの結疁粒界に等化アルミニウムが析出する ために，そのような肺性が現われるものであるうと推論 している。

\section{5）鋳鋼あるいは鋼塊の高温割れにおよばす影響}

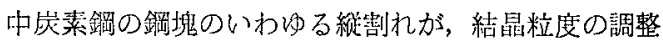
のために添加される Al によって増加することが知られ ている，ての場合の中炭素鋼は，制れの伝播が容易な， 狭いフェライトで用まれたパーライト組織である。

Irvine および Pickering ${ }^{16}$ は，フェライトネット中 に析出した窒化アルミニウム，あるいは硫化アルミニウ ムが，割れの発生起点となるためではないかと推祭して いる.

Desai $^{177}$ および Biggs ${ }^{18)}$ は，おなじく中炭素鋼につ いて高温引張り試験を行ない，Al の添加による 600〜 $700^{\circ} \mathrm{C}$ での延性の減少が，鋼盘割れの王象亡関係がある けしている。このような研究の結果加ら，加引はとも に, さきの Irvine らの考えとおなじく，Al の添加に よる割れの增加は，窒化アルミニウムの析出によるもの ではないかとのべている。 


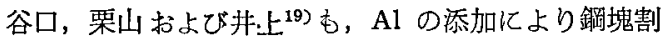
れの增加するととと，化学分析による窒化アルミニウム 量の增加とに関連のあるととを示し，上にのべた諸研究 の結果と打なじく，鋼塊割机は窒化了ルミニウムの析出 によるものではないかとしている。

なお，てれよりさきに，大竹および守田202は，アルミ キルド鎝で高温伸びの減少する現象を，“特殊熱脕性” と題して報告しているが，てれも窒化アルミニウムの影 響が現われたものと考えられる。

\section{6）低炭素鋼の引張り强度におよぼす影䈉}

フェライト・パーライト組織の低炭素鋼に $\mathrm{Al}$ を添加 すると, その引張り強度, とくに降伏点を增加させるて とが知られている。これは，窒化了ルミニウムの析出に よる結晶組織の微細化と，フェライトの樹出硬化による あのと考えられている.

Wiester, Bading, Riedel および Scholz ${ }^{21)}$ は，Alを 添加して，トーマス転炻鋼中のN窒化アルミニウムと して析出させるととによって，降伏点が增加することを 示している.

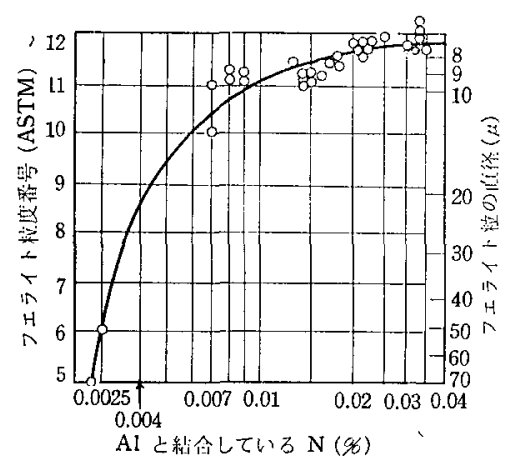

図一1 焼ならし処理した低炭䋆鋼のフエライト 粒度におよばす窒化アルミニウムの影㗽 (瑨ならし処理 : $900^{\circ} \mathrm{C} \times 1 \mathrm{~h}$, A.C.) (Straky および Wiester ${ }^{21}$ による)

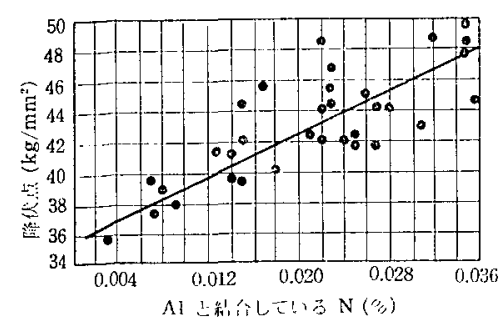

図一2 瑨ならし姏理した低炭菜マンガン鋼の降 伏点に拉よ玨す窒化アルミニウムの影響 (C $0.13 \sim 0.20 \%$, Si $0.30 \sim 0.60 \%, \mathrm{Mn}$ $1.30 \sim 1.66 \%$, P 0.04 max., S 0.04 max.) (Wiester ${ }^{21)}$ による)
図一1および図一2 は，Wiester ら したものである．図一1には，低炭素鋼の焼ならし材の フェライト粒度が, 窒化アルミニウムの量ととあに微細 になることが示されている，図一 2 には，低炭素マンガ ン鐥の㛙ならし材の降伏点が，おなじく窒化アルミニウ 么の量之とあに加なり增加するととが示されている。

普通の電気炉鋼は， $\mathrm{N}$ を $0.010 \%$ 前後は含有してい る.したがって，Al を添加した焼ならし材では，およ そ $0.01 \%$ 程度の N が， $\mathrm{Al}$ と結合して窒化了ルミニウム として析出している. 図一1 から,ての程度の窒化了ル ミニウムの析出が, フェライト結晶粒度の微細化に非常 に有効であるととがわかる.

ドイツには，Al を添加した鋼を比較的低温で圧延す ることによって，降伏点を增加させた溶接構造用鋼板 50 HSB がある. 窒化了ルミニウムが析出するような比 較的低温のオーステナイト域で熱間圧延を行ない，窒化 アルミニウムの析出硬化により降伏点を増加させたもの であるとわか国でば紹介されている22),23)，压延のまま の鋼板の機械的性質におよぼす低温生延の效果が非常に 大きいととを考えると, 窒化アルミニウムによる析出硬 化の效果は副次的なものであろう.

\section{7）低炭素鋼の鞄性におよぼす影豐}

Al の添加に上って鋼のオーステナイト粒が微細化さ れ，さらにフェライト粒も微細化されることは，さきに のべたが，その結果，鋼の朝性す改善される。

とくに溶接構造用に使用される低炭素鋼では, 歎性が 重要であり，高い衙揧値などが要求されてきたために， A1 の添加が一般に行なわれるようになってきた。普通 には，酸可溶の $\mathrm{A} 1$ として $0.02 \sim 0.07 \%$ が使用されてい る.

Wiester ら ${ }^{212}$ は,さらに多星の窒化アルミニウムによ る,フェライト粒の一層の微細化，降伏点の増加，なら びに溶接熱影響部の脆化の防止などの目的で，故意にN を多量に添加することの効果について報告している.

フェライト粒の微細化ちよび降伏点の增加の効果につ いては，上に紹介したが，Wiester らは，さらに窒化了 ルミニウムを多星に含有する低炭素マンガン鋼板のア一 ク溶接熱影響部の組織が粗大化しないこと，そのため熱 影響部の硬化の程度も減少しているととを示している。

Wiester らの研究は，Nの含有量の高いトーマス転炉 銊の問題から出発した研究である。しかしながら，転炉 鋼に限らず平炉鋼でも，“故意に”N $\mathrm{N}$ を添加して，窒化 アルミニウムの効果を利用できるととを，Wiester らは その報告 ${ }^{21}$ の中で推論している.

故意に多量に添加したNの效果については，筆者屯さ 
っそく追試を行なったが，のちにのべるように，低炭素 鋼ではそ机ぼ効果は大きいものではなく，とくに歪時 効脆性の点では悪い影響が明らかであった。したがっ て，一般の溶接構造用としては，自然に鋼中に含有され る 0.006 0.012\% のNで適当ではないかと考えられる.

その後, 中村, 栗山, 雑賀抢上び深川24),25う も同様の 追試を行なっているが，それによれば，窒化了ルミニウ ムを多量に含有させると，鋼板の母材のシャルピー衝撃 試験の成績が向上することを示して, Wiester らの結果 とは一致しているようである.

中村らは, そのような窒化アルミニウムの多量の添加 の効果が, フェライト・パーライト組織の低炭素鋼のみで なく，マルテンサイト組織の低炭素合金銅にもみられる ことを報告しているが，同一の引張り強度レベルでの比 較が行なわれていないために，不明確な点が多い，たと えば，窒化了ルミニウムが結晶粒を微細化して，焼入性 を娍少させるために，引張り強度が低下する場合にも， その引張り強度の低下に基ずく䩗性の向上については考 虑されていない，窒化アルミニウムの添加による䩓性の 増加分の中には, 引張り強度レベルが低下したための分 あ含まれているから，ての分を除か将ばならない。また 溶接性については，溶接熱影響部のシャルピー衝撃試験 結果を中心に，かなりの量のデータが示されているが， 適切な比晬材が用いられていない場合が多く，はっきり しない。

最近, 豊島, 合田, 権藤㧍よび尾上 ${ }^{26)}$ は張り強さが 80 キ口級の低合金高張力鋼板へのNの多量の添加の効果 を報告している．それによれば，窒化アルミニウムを多 量に含有させた銅を，普通に $900 \sim 950^{\circ} \mathrm{C}$ から水焼入れ した場合，焼戻し温度を変えなくとも，Nを普通量しか 含有しない鋼に比皎して $15 \mathrm{Kg} / \mathrm{mm}^{2}$ 程度も引張り強さ が増加する現象などが示されているが，その機構は理解 できない。

溶接構造用鋼と窒化アルミニウムの関係については, 最近とくにその靶性への影響について関心がもたれてき たが，以上の上うに，試験材の拱択や試験結果の考察が 不完全であったり，その機構が解明されないままに放置 された報告が多い。

\section{8）その他の現象}

窒化アルミニウムが直接位影を书よほしている現象 ではないが，やはり窒化アルミニウムが関係している現 象として，つぎのようなものが知られている.

i）歪時效および焼入時効

いわゆる歪時効および焟入時効の現象は，おむに，鋼 中に固溶している遊離の $\mathrm{N}$ によるものと考えられてお
り，てのNを窒化アルミニウムとして固定するととによ って，てれらの時効現象を阻止するてとができる.

熱間庄延のまま使用される䤱板では，たとえ $\mathrm{Al}$ を充 分に添加していても，正延のままでは $\mathrm{Al}$ によるNの固 定が十分には行なわれないので，焼ならし処理などのよ うに $900^{\circ} \mathrm{C}$ 前後に再加熱してはじめて $\mathrm{Al}$ に上る効果を 期待できる.

ii）クリープ強度

A1 の添加は，炭素鋼のクリープ強度を低下させるこ とが, Glen ${ }^{27)}$, Bardgett および Gemmill128)ならびに寺 井 ${ }^{29}$ らによって明らかにされている。

寺井によれば，炭素鋼のクリープ強度を支配する大き な因子の一つは，鋼中に“固溶している N”であるとい う. Al を添加して窒化アルミニウムを析出させ，その 結果，鋼中の固溶窒素の量が減少すると，クリープ強度 はいちじるしく低下する，固溶窒素の量とは，銅中の全 窒素量から，エステル・八ロゲンによる溶解残渣中のN の量を差し引いた值である．エステル・ハロゲン残渣中 には，窒化アルミニウムのほか窒化珪素などむ含まれて いる． $0.001 \%$ の固溶窒素が，炭素鋼のクリープ形度に 大きい影響を扰よばしているようである。

したがって，Nをとくに多く添加して，固溶空素の量 を增加することによって，炭素鋼のクリープ強度を一段 と增加させることができるように思われる。

また，とのようなクリープ処理をうりた鋼中の窒化了 ルミニウムの形態について，最近とくに関心があたれて いる。

\section{iii）応力腐食割れ}

Wader および McDonald ${ }^{30}$ によれば，龬中にNが遊 離して存在していると，軟鋼の応力腐食割れを促進する が，AI の添加はこれを防止する勃果があるという.

以上にのべた諸現象のほかにあ，のちにのべるよう に，炭素鋼の高温延性にも窒化アルミニウムが影響して おりまた溶接構造用鋼の溶接割れにも窒化アルミニウ ムの影響が考えられる。

\section{III. 鋼中の窒化アルミニウムの形態}

うえにのべた諸現象はいずれも，Beeghly2) のエステ ル・ハロゲンを使った化学分析法による窒化アルミニウ ム量と銅の諸性質との関連性について調査して得られた 成果である，てのような研究は，䤱中の堂化アルミニウ ムの形状や分布を直接に観察していないために，窒化了 ルミニウムの影響する機構を明らかにするまでにはいた っていなかった。

したがって，窒化アルミニウムと関連のあるとと見が 
出されても，その機構については，ばくぜんとした推察 が行なわれているにすぎない状況であった，それは多く の場合，鋼中の窑化了ルミニウムが微細な析出物であ り，光学顕微鏡によっては，とうてい観察できない大き さのものであったためであろう.

鋼中の窒化了ルミニウムを直接に観察しようとした研

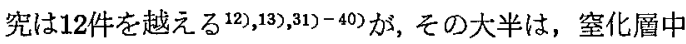
に析出した窒化アルミニウムと推察される大型の分在物 を，光学顕微鏡で観察したものである．窒化層中の窒化 アルミニウムを電解分離法によって抽出して，その透過 光の顕徽鏡像を示している屯の，また二二段レプリカあ るいは溶解抽出残楂を露子顕微鏡で観察したのもある。

これらの顕微鏡写真の中で，鋼中の室化アルミニウム が鋼の性質におよぱす影響を端的に示すととに成功した Dは，Woodfine ら ${ }^{38}$ 功報告した，鋳䤱中に析出した窒 化アルミニウムの光学顕微鏡写真のみであろう．そのほ かのものはいずれも，窒化アルミニウムを抽出してみせ たにすぎなかった。

てのようなととからまず鋼中の窒化アルミニウムの 挙動を詳細に観察する必要が痛感された，笋者は，鋼の 諸性質におよぽす窒化了ルミ二ウムの影響について，そ の機構を明ら加炕する目的で，まず鋼中の等化アルミ二 ウムの形態について, 抽出レプリカ法により直接に電子 顕微鏡下で観察を行なった ${ }^{413,42) 。}$ 。いで，以前からの 問題であるオーステナイト結晶粒度と窒化アルミニウム の関係などの諸現象のほか，鋼の高温延性あるいは溶接 割れと窒化アルミニゥムの関係などの新らしい課題につ

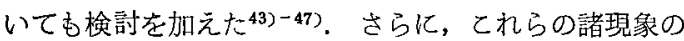
究明化関連して，窒化アルミニウム以外の $\mathrm{Ti}, \mathrm{Zr}, \mathrm{V}$ お よびBなどの各窒化物についても調查を行なっだ8).

ここでは，鋼中の窒化アルミニウムの析出形態につい て観察したところをのべ，てのような観祭の中に，鋼の 性質に打上ぼす窒化了ルミニウムの影響を知る重要な七 ントが含まれているてとを紹介しよう。

\section{1）オーステナイト中の窒化アルミニウム}

低炭素鋼を用いて， $\mathrm{Al}$ および $\mathrm{N} の$ 含有量，さらに熱 処理によって，オーステナイト中の窒化アルミニウムの 形態がどの上うに恋化するかを調べた結果は，つぎのよ うであった。

写真一1は，平炉鋼の焼ならし試料より抽出された窒 化アルミニウムである.フェライト中に微細な長方形の 窒化了ルミニウムが散在しているのがみられる，長さが $0.1 \mu$ 以下の微細なもの无観察されるのが，腐食生成物 が付着しているために，その形状のはっきりしないもの が多い.
$\mathrm{Al}$ および $\mathrm{N}$ の含有量のと屯に高い試料では， $1350^{\circ} \mathrm{C}$ で固溶処理を行なったのちにもなおわずかの窒化了ル ミニウムが残留しているのが認められる，写真一 2 亿み られるように，高温でしかも長時間加熱されると，大型 の棒状に凝集してくる。

写真一 3 抢よび 4 は，写真一 2 とおなじ試料を，固溶 処理したのち，それぞれ $1100^{\circ} お よ ひ ゙ ~ 900^{\circ} \mathrm{C}$ で再加熱 した場合である.析出物はその数を增し，小型になる。 その形状は，長方形の薄い板状である，長さはいろいる で， $5 \mu$ を越える長大なものや，0.1 $\mu$ 以下の微細なもの が認められる.また, その電子線回析像から, 鋼中の窒 化アルミニウムは六方晶の AlN であることがわかる.

Al 扔よび N の含有量が少ない試料はど，おなじ温度 で析出する窒化アルミニウムは微細となり, 長さが $0.1 \mu$ 以下の屯のが無数に散在した状態になる。これは窒化ア ルミニウムの析出量が少なく，したがって析出物が凝集 しにくいため上考えら机る。

図一3には，写真一 $2 \sim 4$ の試料む含めた各種の低炭 素鋼のエステル・八ロゲン法による窒化アルミニウムの 分析結果を示した.

写真一 5 は，固溶温度加ら徐冷した場合に析出した窒 化アルミニウムである. 大型の窒化アルミニウムは，高 温度で徐冷中に析出し, 成長したあのであり, 此較的小 型のものは低温度で析出したすのと思われる。長さが $0.1 \mu$ 前後の微細なものは，乙こでは認められない。写 真一6のように，非常に大型のものが抽出される場合も あった。なお，低倍率で観察すれば，窒化アルミニウム はオーステナイト粒界連らなって析出しているようで ある.

写真一7 7 鍛造した低炭素鋼加ら小型の引張試駼片 を採り，とれを固溶処理したのち，水冷しないですすば やく $1000^{\circ} \mathrm{C}$ の炕に移して，その温度で引張り破断した 試料倸柮していた窒化アルミニウムである，長さが

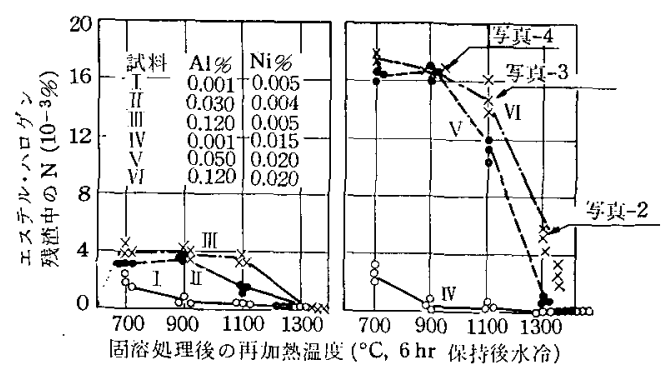

図一3 固溶処理 $\left(1350^{\circ} \mathrm{C}\right.$ 水冷) 後, 各温度に $6 \mathrm{hr}$ 加熱し, 急冷した低炭素鋼のエス テル・ハロゲン法による窒化アルミニ ウムの分析值 $\left(700^{\circ} \mathrm{C}\right.$ では窒化珪素む 含まれている) 
$0.5 \mu$ 程度の窒化アルミニウムが連らなっているのが認 められる。 てれは固溶処理温度 $\left(1250^{\circ} \mathrm{C}\right)$ 加ら $1000^{\circ} \mathrm{C}$ までの冷却中にオーステナイトの粒界にそって析出した ものと思われる.

このように固溶処理後等温加熱した場合には，窒化ア ルミニウムはおすにオーステナイトの粒界に析出する。 また，温度が低いほよ゙，さらに Al および N の含有量が 少ないほど, 微細である。その理由も, 窒化アルミニウ ムの析出量が少なく，したがって析出物が凝集しにくい ためと考えられる。

\section{2）鋳鋼中の等化アルミニウム}

高周波炉で溶製した $50 \mathrm{Kg} の$ 鋼塊について，窒化アル ミニウムの鋳造のままでの析出状態を調查した。鋼塊は 鋳鉄製の鋳型の中で放冷したままの直径およそ $140 \mathrm{~mm}$ の丸型である。

写真一 8 は低炭素鋼塊の中央部より抽出された析出物 である. 粗いパーライトがあるため，カーボン膜の㔀離 が容易でないので，試料を $750^{\circ} \mathrm{C}$ に急熱し，ただちに水 冷して，パーライトの部分を一部マルテンサイトに変え ている. 写真には，鋼塊凝固後の泠却中にオーステナイ トの䊀界に析出したと思われる窑化アルミニウムの析出 線亡，低温度でフェライト中に析出したと思わ机る分散 した䇪化アルミニウムが認められる.さらに高倍率で観 察すれば，窒化アルミニウムの長さは $0.02 〜 0.1 \mu$ であ

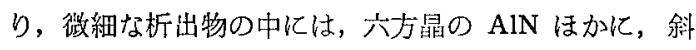
方晶の $\mathrm{Si}_{3} \mathrm{~N}_{4}$ あ含まれているようである.

写真－8の試料（酸可溶の Al $0.042 \% ， \mathrm{~N} 0.016 \%$ ) より屯 $\mathrm{Al}$ の含有量の多い試料（酸可溶の $\mathrm{Al} 0.130 \%$, N $0.019 \%$ ) 加ら抽出される窒化アルミニウムには，長 さが 0.5 1 1 0 ののが多く, $0.1 \mu$ 程度の微細なものは 少なくなり，線状に連なった個々の析出物の間隔は広く なってくる.

写真一8は低炭素鋼の場合であったが，中炭素鎡塊の 中央部では, 網状のフェライトの中央部に窒化アルミ二 ウムの析出線がみられる、公化アルミニウムがさきにオ ーステナイトの粒界に析出したあと, そのオーステナイ 卜䊒界からフェライトが生成したものであろう。

鋼塊の表面層では，析出物は内部よりも一尿微細であ り, 線状に連なっては析出していない，表面層では，高 温における冷却速度がその中央部より屯速いために，才 ーステナイト域での析出が押えられるためであろう。

\section{3）フェライト中の潌化アルミニウム}

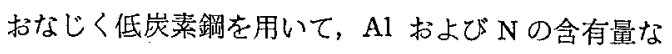
らびに熱処理によって，フェライト中の窒化アルミニウ
ムの析出形態が変化する状況を観察した.フェライト域 では, 窒化アルミニウムのはかに, セメンタイトや窒化 珪素が同時に析出する.

写真一 9 は, $1350^{\circ} \mathrm{C}$ に加熱し, ついで水泠の固溶処 理を加えたのち， $700^{\circ} \mathrm{C}$ で $6 \mathrm{hr}$ 加熱した場合である. 大型の粒状の析出物は $\mathrm{Fe}_{3} \mathrm{C}$ であり，長方形の板状の抽 出物が AlN である，電子線解析によれば， $\mathrm{Si}_{3} \mathrm{~N}_{4}$ む少 量含まれているようである。

写真一 10 は，写真一 9 とおなじ試料を， $1350^{\circ} \mathrm{C}$ で固 溶炕理後水冷しないで, $700^{\circ} \mathrm{C}$ で等温加熱した境合であ る. $700^{\circ} \mathrm{C}$ で $2 \mathrm{hr}$ 保持したのち，この温度から水冷し た、フェライトからは微細な析出物が抽出されている が，オースデナイトはは，そのような析出物はみられ ない.とのように，オーステナイトとフェライト域にお ける窒化物の溶解度と析出速度には差異が認められる。

写真一11は，写真一10のフェライト中の析出物を高倍 率で観祭したものである. 長さが $0.02 \sim 0.1 \mu$ の徽細な 析出物が,フェライトの亜粆界に析出しているようであ る. 長方形のものが AlNで，粒状をしたものは $\mathrm{Si}_{3} \mathrm{~N}_{4}$ で あろう。

なお，写真一11のように固溶処理後等温加熱した場合 に析出する䇪化アルミニウムと，写真一 9 のように固溶 処理後水冷し再加熱した場合に析出するものと比較すれ ば, 後者の場合にみられる窒化アルミニウムのほうが大 きいととがわかる：とれは，同時に析出するセメンタイ トが, 窒化アルミニゥムの析出を促進するためと考えら れる。

粒状の析出物が窒化珪素であることは，Al を含有し ない試料の電子線解析の結果からす推察されるのである が，窒化層や珪素鋼板に関する研究の結果 ${ }^{499,50) 之 屯 一 ~}$ 致している. Al を含有しない試料です，エステル・八 ロゲン法によって化合物型の窒素が分離定量されるが; これは粒状をした窒化珪素の析出によるものであるう.

また，前項のオーステナイトの場合とおなじく，Al お よびNの含有量の少ない試料ほよ゙，おなじ温度で析出す る窒化アルミニゥムは微細であるが，これは空化アルミ ニウムの析出量が少なく，凝集しにくいためであろう.

写真一 12 は， $1250^{\circ} \mathrm{C}$ に加熱後空冷の固溶処理を加え た低炭素鋼板を，冷間圧延し，ついで再結晶烘鈍を行な ったものについて観察した結果である。粒状の香のは， お屯に腐食生成物の硝酸第二鉄であり，それ儿空化珪素 が混在している屯のと思われる. 針状の窒化アルミニウ ムは、フェライトの粒界にとくに析出するというのでは なく，分散して析出しているが，偏析が浔められ，その 析出層が冷間圧延の方向に平行に分布している. 


\section{4）鋼の諸性質と鋼中の窒化アルミニウムの形態}

以上，鋁中に析出する窒化アルミニウムの挙動につい て，その概要を紹介したが，てのような観察の結果は， 窒化アルミニウムが鋼の諸性質におよ涩す影響について 考察するとき役立つように思われる，乙れらの観察の 中に，窒化了ルミニウムの影響を知る重要なヒントが含 まれているというととができよう，つぎに，その二，三 の例についてのべる.

窒化アルミニウムが， $\mathrm{A} 1$ や $\mathrm{N}$ の含有且, さらに熱処 理によって，どのように変化するかを観察したが，てれ はすーステナイト粒度と窒化アルミニウムの関係につい て検討するのに役立つようである．溶接榡造用鋼におり るオーステナイト粒度の問題は，その母材扔よび熱影響 部の欨性などの性質に関係があるために重要であるが， のちにのべるように，オーステナイト粒度と窒化アルミ ニウムの析出形態の間には，密接な関係があり， $\mathrm{A} 1$ や の量, 高温加工, あるいは熱履歴などによる粒度の変化 は，いずれ屯窒化アルミニウムの析出形態の変化と関係 づけるととができるように思わ机る，また，鋼盘から採 った鋳造材と，それを鍛造した鍛造材とで，あるいは鋼 塊の大きさによっても，オーステナイト粒度に差がある ことが認められているが，乙れらの問題の機構も解明で きるように思われる。

$\mathrm{Al}$ が脱酸やオーステナイト粒度の調整のために使用 されるようになってから，Al の添加によって鋼塊割れ が增加するととは，製鐝工塲の大きな問題の一つであっ た．てれまで, 硫化物の網状組織が原因であろうとか, あるいは窒化アルミニウムの析出膜の生成が原因ではな いかといわれながら、はっきりしていなかったあのであ る. さきに示したように，抽出レプリカ上に，オーステ ナイトの粒界に連らなって析出した窒化アルミニウムの 析出線が認められたが，乙のような析出線の存在が，鋼 の高温延性を低下させるととが考えられょう，鋼塊の割 れが Al の添加によって增加するのは，とのような高温 延性の低下と関連があるものと推祭される。

そのような窒化アルミニウムの析出線は，溶接による 割れに屯原因となるように考えられよう。

また，鋼塊の割れや，溶接による割れが，窒化アルミ 二ウムの析出線の生成が原因で発生するあのであれば， その防止対策もおのずから明らかであるということがで きよう．てのような考えから，窒化アルミニウム以外の 室化物の鋼中における析出形態について，空化アルミニ ウムとの比較調查を行なった。

鋼の諸性質と窒化アルミニウムの形態との関連につい て調べた結果をつぎにのべるが，乙れらの研究はいずれ も，上にのべたような考察から出発したものである。

\section{IV. オーステナイト粒度と窒化 アルミニウム}

エステル・八ロゲン法によって残渣として分離定量し た窒化アルミニウムの量と, オーステナイト粒度との関 係については, Born らの研究らははじよして, 最近 にいたるまで多くの報告があり，窒化アルミニウムによ る結晶粒微細化作用や粗粒化阻止作用についてばくぜん とした論議が行なわれたが，その機構についてはよく知 られていなかった。

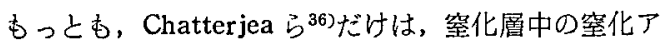
ルミニウムと思われる大型の析出物を光学顕微鏡によっ て観察し, 窒化アルミニウムの固溶現象を単に化学分析 で調查するだけでなく，その析出形態の变化にも注意す る必要があるとのべていた。

ここでは，オーステナイト粒度に影響する諸因子につ いて調查した結果をのべる，オーステナイト粒度の問題 は, 単に母材の性質ばかりでなく, 溶接熱影響部につい て考える場合にあ参考となることはいうまでもない。

\section{1）オーステナイト粒度と Al および $\mathbf{N}$ の量}

酸可溶の $\mathrm{Al}$ を $0.002 \sim 0.124 \%$ 含有する中炭素鋼を供 試材として，まず Al の量の影響を調查した，熱履歷が 粒度に影響するので, 鍛造前の加熱温度, 銠造終了温度 などをそろえる必要がある.

酸可溶の $\mathrm{Al}$ が $0.124 \%$ の試料は，0.05\%の試料よりも かえって粗粒となる.てれは窒化アルミニウムの析出形 態の相違によるすのと思われる。

すなわち， $50 \mathrm{Kg}$ の鋼塊を $1000 \sim 800^{\circ} \mathrm{C}$ の間で銉造 した場合，Al の量を異にする鋼塊では，窒化アルミニ ウ ムの析出形態の差異が銭造後も残る. 酸可溶の $\mathrm{Al}$ が $0.124 \%$ の試料之 $0.03 \%$ 前後の試料とを比較すれば，前 者では大型の空化アルミニウムが多いのに対して，後者 では微細なものが多い，高温で長時間加熱すると，窒化 アルミニウムは凝集して大型となる傾问がみられるが, $1000^{\circ} \mathrm{C}$ で $6 \mathrm{hr}$ 加熱しても両者の差異は残存している.

つぎ低炭素鋼を用いて，Nの量の影響を調査した。 図一4は，Nの量を変えて窒化アルミニウムの量の影嚮 を調查した結果である，窒化アルミニウムをとくに多く 添加して屯，粗大化温度にそ机はど大きい影響はない

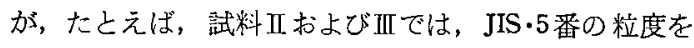
示す滲炭温度が $75^{\circ} \mathrm{C}$ 前後は上梨している. しかし，て てでも Al がとくに多い試料IVではその效果がなく，窒 化アルミニウム量の少ない試料Ｉよりも加えって粗粒と なる傾向がみら机る。

また，図一 4 から，䇪化アルミニウムの量が多い試料 


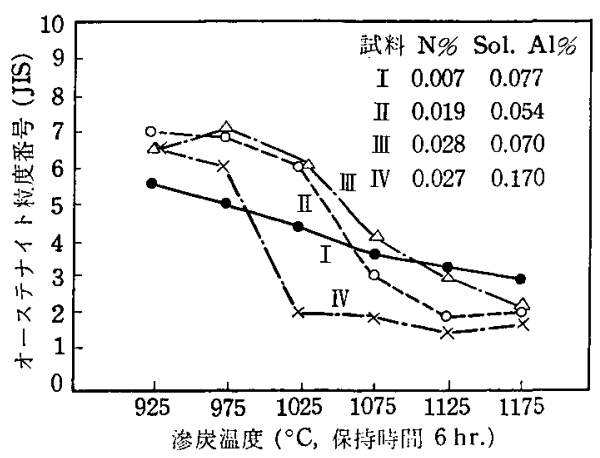

図一-4 低炭素銅のオーステナイト粒度におよ 淁す窒化アルミニウムの影響

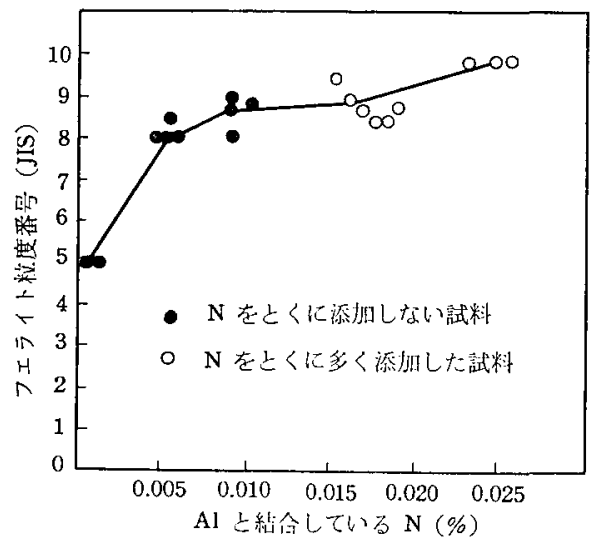

図一5焼ならし処理した低炭素鋼のフエライト 粒度におよぼす窒化アルミニウムの影響

の $925^{\circ} \mathrm{C}$ に拉りる粒度は，1番以上細かくなっている こともわかる，さきに図一1にみられたようなフェラカ 卜粒度微細化の効果む，おもにてのようなオーステナイ 卜粒度への影響が現われたものであるう。

図一 5 は，図一 4 とおなじ低炭素鋼の焼ならし材につ いて、フェライト粒度と窒化アルミニウム量の関係を追 試したるのである. AlN の形の N が 0.005 0.010\%に なると、フェライトの細粒化の効果がいちじるしい.

\section{2）オーステナイトの混粒}

益子 ${ }^{52}$ 亿よれば，混粒は “偏在型の混粒”之“混在型 のもの”とに分類できるが，それらの混粒の生成原因は つぎのように考えられる.

層状偏在型の混粒は，一次オーステナイトの粒界付近 に析出した窒化アルミニウムが，鍛造によって層状の偏 析をつくるために発生する. 混在型の混粒は, 空化了ル ミニウムの凝集あるいは固溶による消失が原因で発生す るあのと考えられる。

\section{3）オーステナイト粒度と鋼塊の大きさ}

酸可溶の $\mathrm{Al}$ を $0.030 \%$ 含有する中炭素鋼を用いて, 100 $\mathrm{Kg}$ の鋼塊と $5 \mathrm{Kg}$ の取鍋試料についてオーステナイト 粒度の比較を行なったところ，䤲造材では，後者のほう が粗大化温度が高かったが，乙れ屯窒化アルミニウムの 析出形態の差異によるすのと思われる。

鋼塊が大きいと，冷却速度が遅いために，鋳造時に大 型の窒化アルミニウムが析出しやすく，それだけ低温で 析出する微紐なるのが少ない，また，一次オーステナイ 卜粒も粗大化し，㻞析の㑯向がつよくなる．乙れに対し て小龬塊では，冷却速度が速いために，微細な析出物の 数が多く，また，一次組織も微細であるために，偏析の 傾向も少ない，とのような窒化アルミニウムの析出形態 の差異は， $1000^{\circ} \mathrm{C}$ で $6 \mathrm{hr}$ 加熱したのちにも残ってお り，粗大化温度に差を生じた原因となっているすのと若 えられる。

\section{4）オーステナイト粒度と高温加エ}

前項で使用した $100 \mathrm{Kg}$ 鋼塊を使用して，鈠造温度と 鍛造比の影響を調查した．䤪造前の加熱温度は，1000， 1150 および $1300^{\circ} \mathrm{C}$ ，鍛造終了温度は，それぞれおよそ 800,950 および $1100^{\circ} \mathrm{C}$ とした。銭造比は $2,5,10$ 亿そ れぞ机変え，鍛造後は空冷した。

鍛造によって粗大化温度は低下するが，鐉造温度の影 響が大きい，鍜造温度が 1150 950C の場合に粗大化 温度はもっとも低く, $1000 \sim 800^{\circ} \mathrm{C}$ の場合にはそれより 屯高く，1300 1100 $\mathrm{C}$ の場合にはさらに高加った。

鍛造比と粗大化温度との間には関係が認めら执なっ た。

鍛造前の加熱温度が，その固溶温度より屯高い場合に 析出する窒化了ルミニウムは微紐であるが， $1100^{\circ} \mathrm{C}$ 前 後の場合には，窒化アルミニウムが凝集して大型の析出 物となる傾向がみられる．加熱温度が低いとそのような 凝集が進行しない，錹造温度，とくに鍛造前の加熱温度 の高低による，てのような窒化アルミニウムの析出形態 の変化が, 粗大化温度の高低の原因になっているものと 考えられる.

\section{5）オーステナイト粒度と熱処理}

前項で使用した中炭素鋼塊を $1000 \sim 800^{\circ} \mathrm{C} て ゙$ 鈠造し， つぎの 3 種類の前熱処理の影響を調查した。

i）固溶処理 $\left(1200^{\circ} \mathrm{C}\right.$ 水冷) 後の再加熱温度の高低 によって粗大化温度は変化する．再加熱温度がそれぞれ $700 ， 900$ および $1100^{\circ} \mathrm{C}$ の場合（加熱保持時間 $6 \mathrm{hr}$ ) には，900 $\mathrm{C}$ で粗大化温度がもっとも高かったままた， 固溶処理後 $700^{\circ} \mathrm{C}$ に再加熱した場合に析出する窒化了 


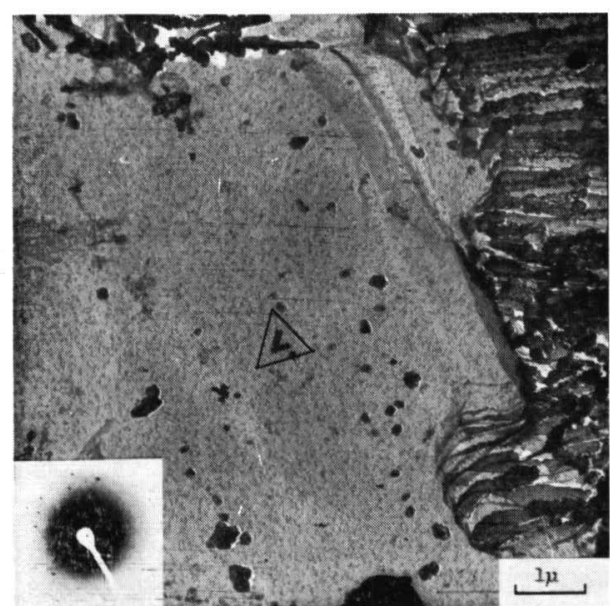

写真一1 鍛造後焼ならし処理した平炉鋼よ り抽出された窒化アルミニウム（C $0.20 \%$, Si $0.30 \%, \mathrm{Mn} 1.34 \%$, 酸可溶の $\mathrm{Al} 0.030 \%$, $\mathrm{N} 0.004 \%, \mathrm{~N}(\mathrm{AlN}) \quad 0.003 \%$ )

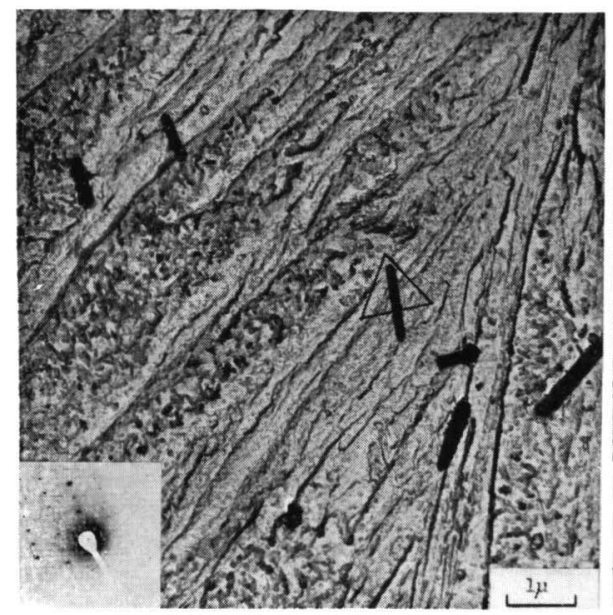

写真一 2 固溶処理後 $\\left(1350^{\circ} \mathrm{C}\right.$ 水冷 $), 1300$

${ }^{\circ} \mathrm{C}$ に $6 \mathrm{hr}$ 再加熱した試料より抽出され た窒化アルミニウム二(C $0.21 \%$, Si $0.28 \%$, $\mathrm{Mn} 1.32 \%$, 酸可溶の Al $0.120 \%$, N 0.020 $\%, \mathrm{~N}(\mathrm{AlN}) 0.006 \%$ )

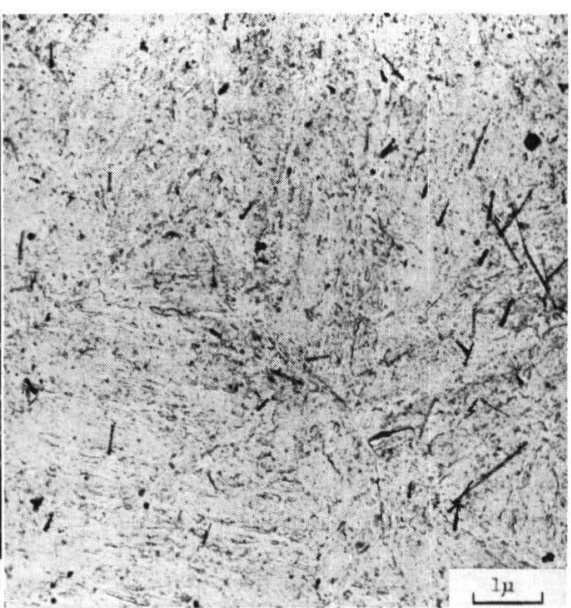

写真一 4 写真一 2 とおなじ低炭素鋼を固溶 処理 $\left(1350{ }^{\circ} \mathrm{C}\right.$ 水冷) 後, $900^{\circ} \mathrm{C}$ に $6 \mathrm{hr}$ 再加熱した試料より抽出された窒化アルミ 二ウム

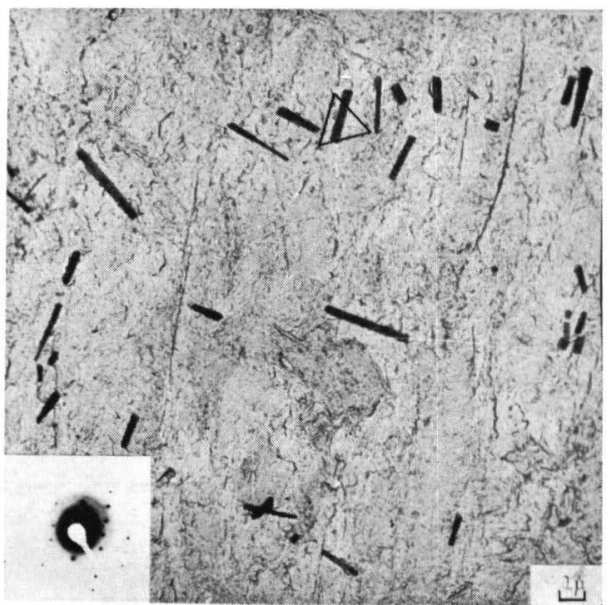

写真一 5 写真- 2 上おなじ低炭素鋼を, 固 溶温度 $\left(1350^{\circ} \mathrm{C}\right)$ より $900^{\circ} \mathrm{C}$ まで徐冷( 泠却速度 $100^{\circ} \mathrm{C} / \mathrm{hr}$ ) したのち水冷した試 料より抽出された窒化アルミニウム

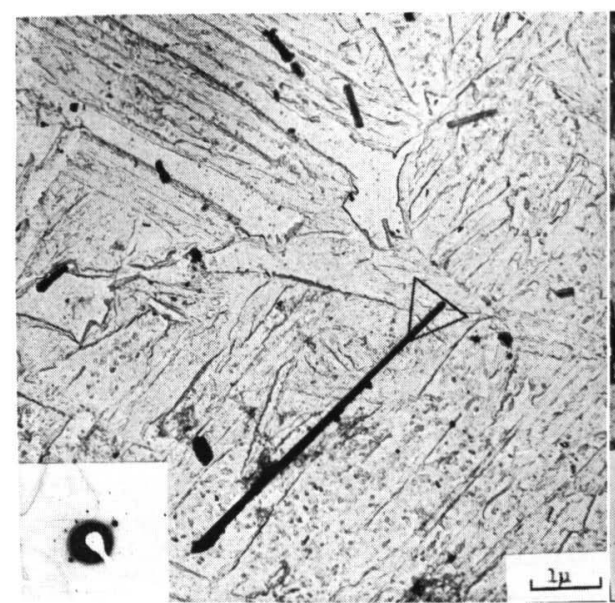

写真一 3 写真 -2 とおなじ低炭素鋼を固溶 処理 $\left(1350^{\circ} \mathrm{C}\right.$ 水冷) 後, $1100^{\circ} \mathrm{C}$ に $6 \mathrm{hr}$ 再加熱した試料より抽出された窒化アルミ ニウム

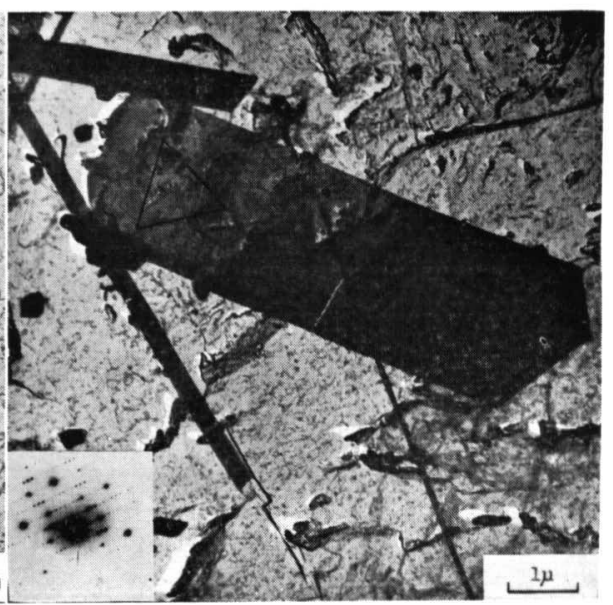

写真一 6 写真一 5 とおなじ徐泠処理をした 試料より抽出された大型の窒化アルミニウ 


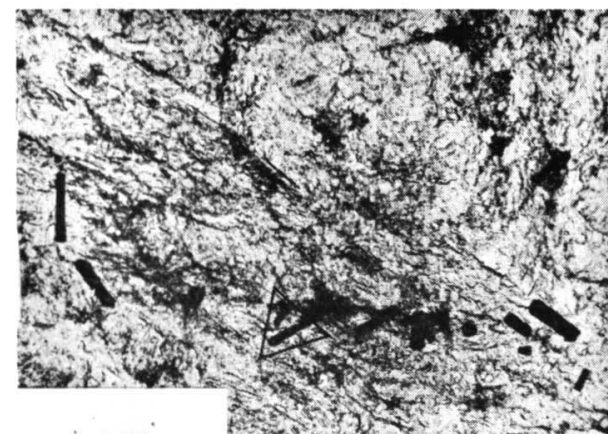

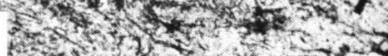

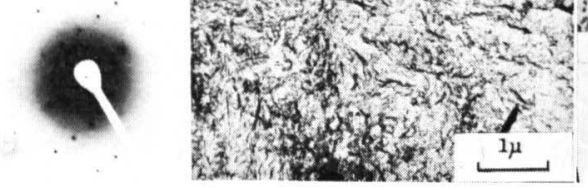

写真一 7 低炭素鋼の鍛造材より採った小型 引張り試験片を, 固溶処理後 $1000^{\circ} \mathrm{C}$ の炉 に移して，その温度まで邻却するのを待っ て引張り, ついで水冷した試料から抽出さ れた窒化アルミニウム（C $0.20 \%$, Si 0.39 $\%, \mathrm{Mn} 1.36 \%$, 酸可溶の $\mathrm{Al} 0.050 \%, \mathrm{~N}$ $0.017 \%$ )

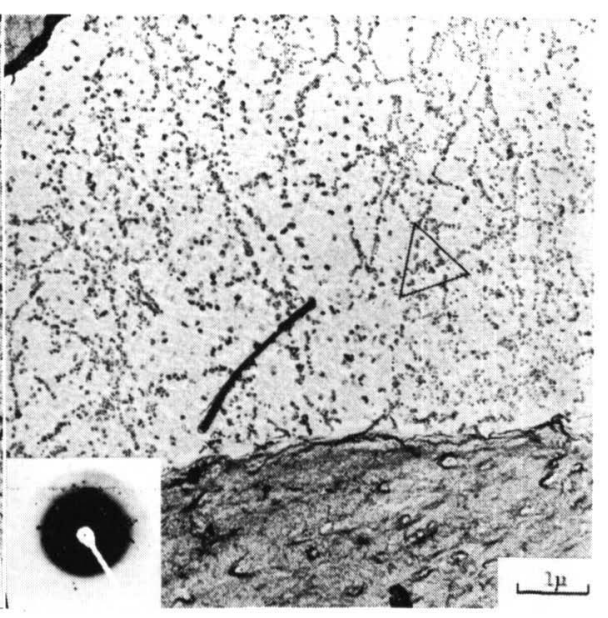

写真一10 写真-9 とおなじ低炭素鋼を固溶 処理後, $700^{\circ} \mathrm{C}$ で $2 \mathrm{hr}$ 等温加熱したのち 水冷した試料より抽出された析出物
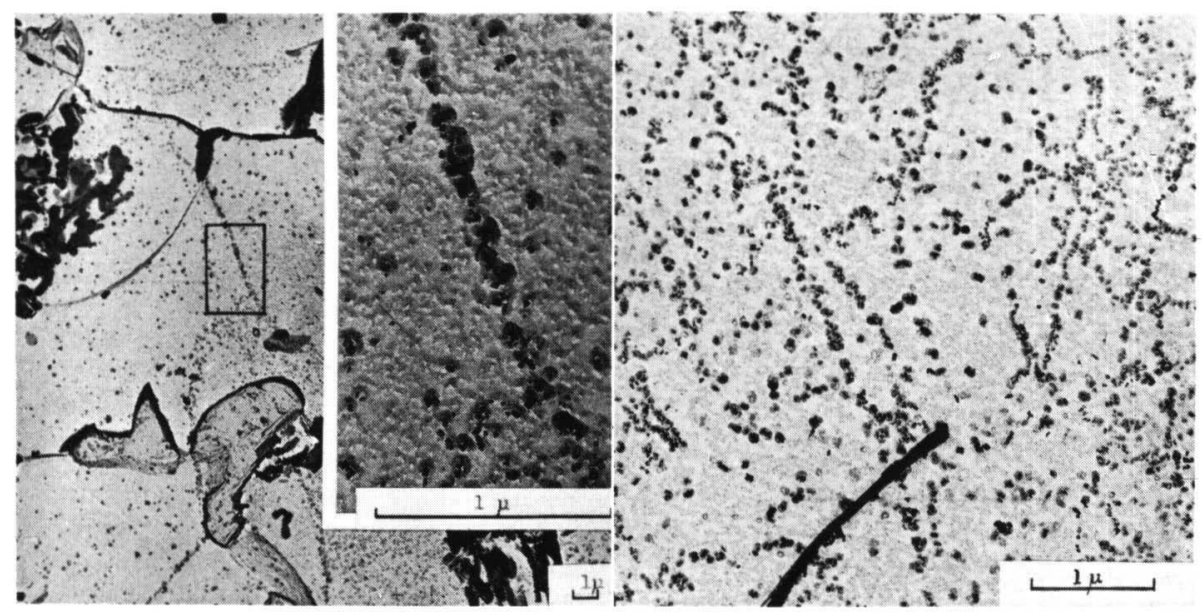

写真一8 $50 \mathrm{~kg}$ の低炭素鋼塊の中央部より 抽出された窒化了ルミニウムの析出線 (C $0.20 \%$, Si $0.27 \%$, Mn $1.40 \%$, 酸可溶の $\mathrm{Al}$ $0.042 \%, \mathrm{~N} 0.016 \%, \mathrm{~N}(\mathrm{AIN}) 0.011 \%$ )

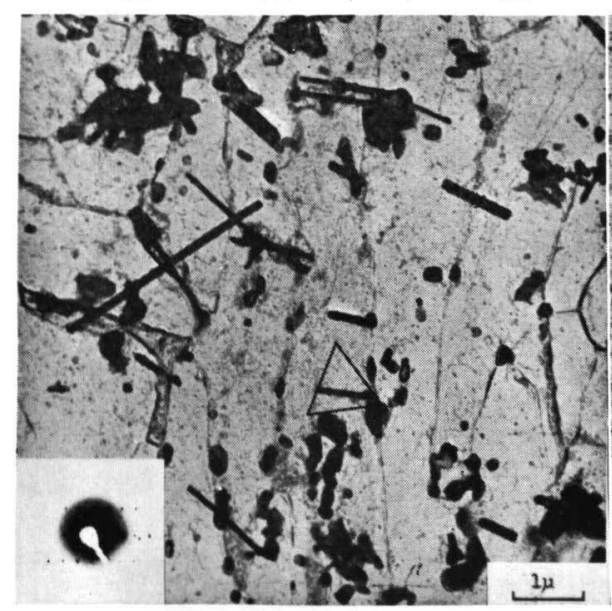

写真一 9 固溶処理後 $\left(1350^{\circ} \mathrm{C}\right.$ 水冷 $), 700$ ${ }^{\circ} \mathrm{C}$ で $6 \mathrm{hr}$ 再加熱した試料より抽出され た窒化アルミニウムと球状セメンタイト (C $0.21 \%$, Si $0.29 \%$, Mn $1.42 \%$, 酸可溶 の $\mathrm{Al} 0.050 \%, \mathrm{~N} 0.020 \%$ )
写真一11 写真一10の一部を拡大したもの： フエライトに析出した窒化アルミニウムと 窒化珪素

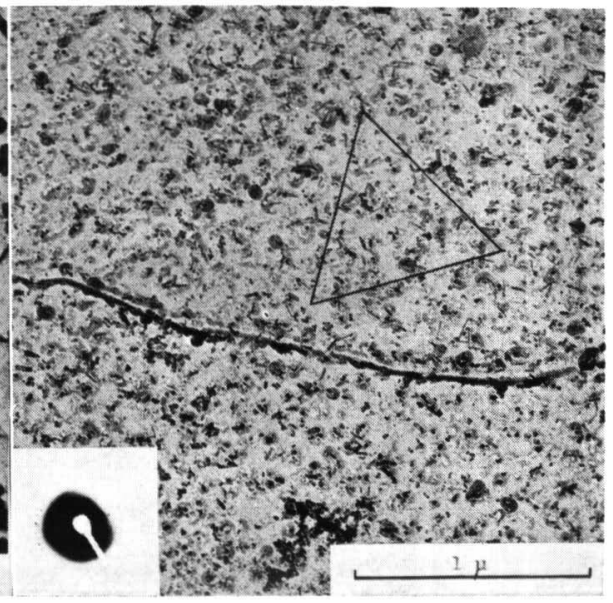

写真一12 固溶処理後 $\left(1250^{\circ} \mathrm{C}\right.$ 空冷), 冷間 圧延し, ついで $700^{\circ} \mathrm{C}$ で $6 \mathrm{hr}$ 焼なまし処 理をした低炭素鋼板より抽出された針状の 窒化アルミニウム $(\mathrm{C} 0.08 \%, \mathrm{Si} 0.01 \%, \mathrm{Mn}$ $0.35 \%$ ，酸可溶の $\mathrm{Al} 0.050 \%$, N $0.015 \%$ ) 
ルミニウムは, $900^{\circ} \mathrm{C}$ の場合よりも長大なものが多かっ た。

ii）固溶処理後の等温加熱温度の高低によって屯, 粗 大化温度は変化する．等温加熱温度がそれぞれ700, 900 および $1100^{\circ} \mathrm{C}$ の場合（加熱保持時間 $6 \mathrm{hr}$ ) には，700 ${ }^{\circ} \mathrm{C}$ での粗大化温度がもっとも高かった。 また， $700^{\circ} \mathrm{C}$ で等温加熱した場合に析出する窒化アルミニウムがすっ とむ微細であった。

iii）固溶処理後の泠却速度の綏急によっても，粗大化 温度は変化する，それぞれ水冷， $600^{\circ} \mathrm{C} / \mathrm{hr}$ および 100 ${ }^{\circ} \mathrm{C} / \mathrm{hr}$ の速度で冷却した場合には， $600^{\circ} \mathrm{C} / \mathrm{hr}$ での粗大 化温度があっとも高く, しかも, 公化アルミニウムはこ の場合にもっとも微細に分散して析出していた。

このように，前等処理の影響も，窒化アルミニウムの

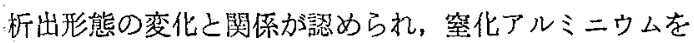

微緗に析出させるほど粗大化温度は高くなるようであ る.

以上，オーステナイト精度に影響する諸因子について 調查し, いずれ揚合にす, 窒化アルミニウムの析出形 態の変化と関連があることを明らかにすることができ た. 従来の研究の結果には，一見相反すると思われるも のあみられたが，乙のような観点に立てば，それらあ統 一して整理するととができるようである。

なお， $\mathrm{Zr}, \mathrm{Ti}, \mathrm{V}$ および $\mathrm{Nb}$ の添加む，オーステナイ ト粒の微練化に有効であり, しかむ, 粗大化温度はそれ らの元紊の含有量の増加とともに上昇し, また, 熱履歴 の影響す少なく，Al の場合と異なっている。乙れは微 細化有効亡思われるこれらの元素の析出物が, 窒化了

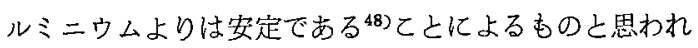
る.

(次号比つく)

\section{第 10 回 F.S 委員会予定}

日 時：炤和39年12月10日（木） 10.00-16.00

場 所：東京大学出版会館

議 事: 1 . 資 料 解 説

(1)「60キロ級高張力鋼の溶接熱サイクル再現部の疲労特性について」

（2）「溶接継手の形状を対象にした切欠材の疲労試験例」鉄研上田四郎氏。

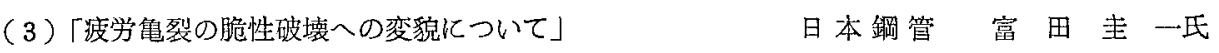
*10月 26 日造船協会 2 分科 6 分科合同委員会で発表したもの
(4)「スラグ溶接部の曲げ爱労」
船研飯田国広氏
（5）「H.T 棒による隅肉溶接部の疲労強度」
石川宜播磨 溧山良員氏外 3 名

（6）「熱サイクル再現装置を使用して熱加工した部材の疲れ試験」

八憣製鉄高 橋 賢 司氏

\section{2. 抄訳カードの説明}

